\title{
Connecting Sacred and Mundane: From Bilingualism to Hermeneutics in Hebrew Epitaphs
}

\section{Michael Nosonovsky}

College of Engineering and Applied Science, University of Wisconsin-Milwaukee, Milwaukee, WI 53201, the United States of America

e-mail: $\underline{\text { nosonovs@uwm.edu }}$

Abstract: Gravestones with Hebrew inscriptions are the most common class of Jewish monuments still present in such regions as Ukraine or Belarus. Epitaphs are related to various Biblical, Rabbinical, and liturgical texts. Despite that, the genre of Hebrew epitaphs seldom becomes an object of cultural or literary studies. In this paper, I show that a function of Hebrew epitaphs is to connect the ideal world of Hebrew sacred texts to the world of everyday life of a Jewish community. This is achieved at several levels. First, the necessary elements of an epitaph - name, date, and location marker - place the deceased person into a specific absolute context. Second, the epitaphs quote Biblical verses with the name of the person thus stressing his/her similarity to a Biblical character. Third, there is Hebrew/Yiddish orthography code-switching between the concepts found in the sacred books and those from the everyday world. Fourth, the epitaphs occupy an intermediate position between the professional and folk literature. Fifth, the epitaphs are also in between the canonical and folk religion. I analyze complex hermeneutic mechanisms of indirect quotations in the epitaphs and show that the methods of actualization of the sacred texts are similar to those of the Rabbinical literature. Furthermore, the dichotomy between the sacred and profane in the epitaphs is based upon the Rabbinical concept of the 'Internal Jewish Bilingualism' (Hebrew/Aramaic or Hebrew/Yiddish), which is parallel to the juxtaposition of the Written and Oral Torah.

Keywords: Hebrew epitaphs, Jewish bilingualism, Hebrew gravestone inscriptions, Judaic hermeneutics, Hebrew epigraphy.

\section{Introduction}

Gravestones play a prominent role among the monuments of Jewish culture still present in Eastern Europe, where Jewish civilization has thrived for centuries. Most of the gravestones have inscriptions ISSN 2299-0518 
in Hebrew. The oldest Ashkenazi gravestones in Eastern Europe are dated with the first part of the $16^{\text {th }}$ century C.E. The total number of Hebrew inscriptions constitutes tens of thousands. Despite their abundance, Hebrew gravestone inscriptions (or epitaphs) are rarely studied by philologists or anthropologists as a literary genre or a phenomenon of culture [13], [14], [18].

The oldest Jewish gravestone inscriptions in Europe are dated with the first centuries before the Common Era. However, most of these oldest epitaphs, as well as most of the inscription from the first millennium C.E., are in Greek or Latin, with only occasional Hebrew words included sometimes [7]. The phenomenon of elaborated Hebrew epitaphs emerged at the turn of the millennia [11]. The appearance of such elaborated texts coincides with the emergence of the rabbinical Judaism in Europe at about the $10^{\text {th }}$ century C.E., as opposed to the earlier Ga'onic Judaism with its centers in Babylonia and in Palestine. Writing epitaphs in Hebrew was a part of a more general process of creating a sophisticated rabbinical culture with Hebrew language playing a prominent role in several areas of the communal life including, but not limited to, the liturgy and religious education [16].

Hebrew epitaphs are related to the rabbinical literature, and in many instances they use the same formulas or lexica as the latter. However, the epitaphs are seldom studied from the viewpoint of the rabbinical logic and hermeneutics.

In this paper, I will discuss the genre of the Ashkenazi Hebrew epitaphs as a hermeneutic phenomenon and will show that the main function of the epitaphs is to connect the ideal world of Hebrew sacred texts (as presented or symbolized by the Hebrew language and the Written Torah, the culture of written texts, and normative, canonical Judaism) to the world of everyday 'mundane' or 'profane' life of the Jewish community (as presented or symbolized by the Aramaic or Yiddish languages and the Oral Torah, colloquial culture, and a folk religion). The actualization of a sacred text is a central problem of hermeneutics, and thus the methods of connecting the sacred to the mundane in the epitaphs are at the very center of the Judaic hermeneutics in general. The material of this study was collected during numerous field trips to Ukraine and other parts of Eastern Europe since the early 1990s [15].

\section{Epitaphs Between the Sacred and Profane}

The epitaphs occupy an intermediate position between the ideal world of the sacred texts and the real world of the everyday life of a Jewish community at several levels.

\subsection{Absolute Coordinates: Name, Date, and Marker of a Place}

Almost every epitaph involves four necessary elements [12, 13, 15]:

First is an introductory phrase. In most cases the introductory phrase is פה נטמן "here lies" (פually abbreviated as פנ). Besides that, sometimes, עציון הזה הגל הזה "this sign," עמן "the is a witness," and some other formulas are used. The introductory formula refers to the burial place and it seems redundant, because the gravestone itself marks the place. As I have suggested earlier [12], [14], this formula corresponds to the function of the epitaph as a marker of a place, where a certain contact with the soul of the deceased is possible. It is important also to mark the ritually impure place of the burial, for example, because the Kohanim are forbidden to go there.

Syntactically, the introductory phrase can be viewed as a subject part of a sentence 'Here lies $\mathrm{X}$ '. However, in many cases the introductory formula is separated from the rest of the text. For instance, the abbreviation פנ is often written on top of a monument separately from the rest of the inscription. The abbreviation פנ is usually present on a Jewish gravestone even if the rest of the inscription is written in a different language, such as Russian. This indicates that starting the mid-18 century, the introductory formula plays a symbolic role of a marker of a Jewish grave, similarly to, for example, a Star of David on the gravestones of the $20^{\text {th }}$ century. 
Second is the name of the deceased person. The name is given in its complete form following a 'title' and often a list of virtues: '[description of virtues] title $\mathrm{X}$ [nicknamed $\mathrm{N}$ ] ben/bat title Y, blessing.' The titles range from a simple $\urcorner R[e b]$ [= 'a man'] to elaborated pleonastic titles, such as the abbreviated הרב הגדול מורנו הרב רבי = הה מוהרר ('The g[reat] R[abbi], ou[r teacher,] R[abbi] R[eb]'). A description of virtues can also range from a straightforward one to an elaborated one. The name is usually presented in its official form, the way a person would be called in an official document, such as a ketubba or get, or when a person is called to read the Torah. The official form of the name is discussed in the treatise Gittin. The standard blessing after the father's name is זכרונו לברכה=) ז' ז' memory is for blessing').

Third is the date of death, which is given in accordance with the Hebrew calendar and the Era from the Creation. The practical value of remembrance of the date of death is that the person can be commemorated on that day of the year (a custom known as yohrzeit in Yiddish). Sometimes, a chronogram is used: a biblical verse with certain letters marked in it, so that the sum of numerical values constitutes the year.

Fourth is a final blessing formula, almost always תהי נפשו צרורה בצרור החיים May his/her soul be bound in the bundle of life' usually abbreviated to תנצבה.

A typical epitaph looks somewhat like this:

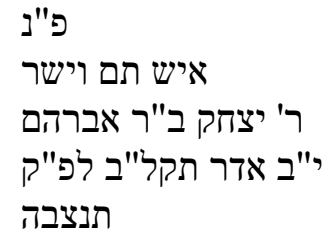

Here lies a simple and righteous man (Job 1:1) R[abbi] Isaac s[on of] R[abbi] Abraham [died on] 12 Adar (5)532 a[ccording to the] M[inor] E[ra] (=1772 CE), M[ay] H[is Soul] $\mathrm{b}[\mathrm{e}$ Bound] $\mathrm{i}[\mathrm{n}$ the Bundle of] L[ife].

In this epitaph, the expression ("a simple and righteous man”) is used as a praise formula in front of the name of the deceased. The title 'Rabbi' does not imply that the person had a rabbinical ordination. It is just a form of politeness or respect. The so-called פרט קטן 'minor era' implies stating the Hebrew year from the Creation of the world without indicating a millennium.

Although these four elements are found in virtually every Hebrew epitaph from Eastern Europe, their functional value is not clear. Why would one, for example, say 'here lies' on a gravestone? Isn't it obvious that a gravestone marks a grave of a person whose body lies under the stone? Why are the date of death, name, and gender such important individual characteristics, unlike, say, an occupation?

One possible answer to this question is that time, place, and individuality constitute an absolute system of coordinates to which the person is related. The mystical Sefer Yezirah ('Book of Creation') mentions three categories: עולם 'olam ('world'), שנה Šanah ('year'), and נפש nefeš ('soul') as a symbolic representation of the space, time, and individuality (or subjectivity). Relating a person to these coordinates by designating his own place, moment in time, and name constitutes a hermeneutic act of connecting with the Absolute.

\subsection{Biblical Quotations}

Various biblical verses are used in the epitaphs, and their function may be different. Often a verse mentioning a Biblical character with the same name as the deceased is used. Below is an example of an epitaph from the town of Buczacz (1792 C.E.): 
And Miriam took the good in her hand, the hand that she prostrated to the poor, and Miriam died there, and she was buried here 23 Ševat (5)552.

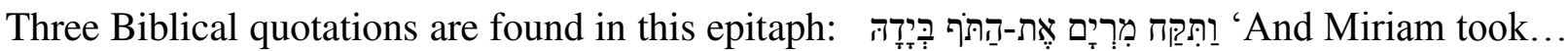

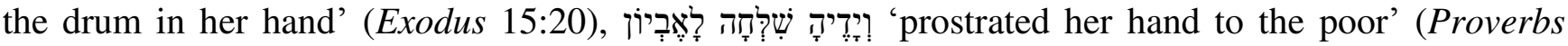
31:20), which means she was generous in giving charity; the verse is from the description of אשת חיל 'a

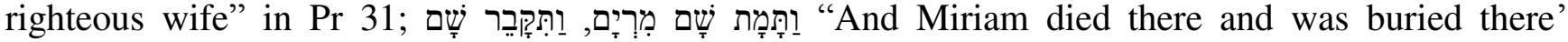
(Numbers 20:1).

In the example above, the purpose of the first quotation is to compare Miryem from Buczacz with Biblical Miriam. The word ז ('good'). The second quotation from the popular liturgical poem אשת חיל ('a righteous wife') based on Proverbs 31, which is recited on Saturday Eve, stresses that this Miryem from Buczacz was a righteous wife like a Biblical ideal. The third verse compares the death of Miryem from Buczacz with that of

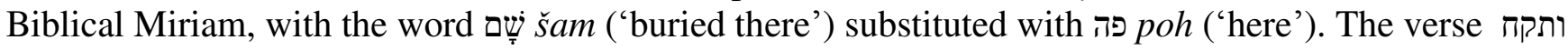
טוב בידה Creation or 1791/2 C.E. when numerical values of the letters are summed up. This compliments the regular way of indicating the year תקנ"ב.

Biblical quotations are actively used when virtues of the person are discussed. The purpose of listing the virtues is to witness in favor of the deceased in the heavenly court. One of the euphemisms of the death is נתבקש לישיבה של מעלה 'He was called to the meeting of the heavenly court.' Thus the epitaph itself serves as a guardian angel for the dead. The connection between the deceased and his or her surviving relatives works in both directions: his/her merit can protect those living, זכותו יגן עלנו 'his merit will protect us' or even זכותו יליץ עלינו ('His merit will be accounted for us'). The praise section of the epitaph is called הלצה ('praise', the same word can mean 'rhetoric') while the epitaph itself is מלינו יליץ, a guardian angel in the heavenly court.

The most common praising formula in the male epitaphs is איש תם וישר 'a simple and righteous ma",, based on Job 1:1. The standard formula in female epitaphs is אשה חשובה וצנועה 'a modest and important woman'. This formula does not have a Biblical source, but the word צנועה ('modest') has certain gender-related implications, while the expression אשה חשובה ('an important woman') is discussed in Pesakim 108a, which states that only an 'important' women should recline during the Passover Seder. Moses Isserles (1520 - 1572) further states that 'in our time' every woman is an important woman [2].

\subsection{Traditional Jewish Bilingualism and Orthography Code-Switching the Epitaphs}

The sociolinguistic concept of the Traditional Jewish bilingualism was developed by Max Weinreich [16]. According to his view, two Jewish languages, such as Hebrew and Yiddish, have two different sociolinguistic functions. In an ideal scheme, Hebrew is a written language used predominantly in written communication. This is not limited to liturgy, Torah studies, and religious treaties. Hebrew is also used for the needs of practical written communications including the correspondence, bookkeeping, communal paperwork (the so-called pinqasim or books of records of various community institutions). Yiddish is a language of predominantly oral communication. This scheme applies to the pre-modern Jewish society of Eastern and Central Europe. The actual or real scheme of bilingualism is different from the ideal one in that on rare occasions Hebrew is used for oral communication, and Yiddish is used for writing, including entertainment literature (mostly intended for women). Note that Hebrew is considered a male language (all boys learn it in a heder, an elementary school), whereas Yiddish is considered of interest for women, who were usually not proficient in Hebrew (and often 
illiterate) and thus unable to participate in Hebrew written communication. Yiddish was considered a mamelošn (mother's language) while Hebrew was associated with the culture of Talmudic and rabbinical studies.

While Hebrew and Yiddish constitute two distinct languages (the first one is Semitic, whereas the second one is Germanic), there were many forms of texts which could be considered intermediate between pure Hebrew and Yiddish. These are either Hebrew texts with a large amount of Yiddish borrowed words or Yiddish text rich with the Hebrew component words. Examples of such texts would include the so-called Scribal Yiddish (the language of some communal documents written in Yiddish with about $50 \%$ or more Hebrew inclusions), secret languages or 'cryptolects' of some merchants (e.g., Lakudeš of late medieval/early modern cattle traders in Germany), the language of Talmudic discussion, rich of Hebrew, and many others. Furthermore, since Yiddish has a significant Hebrew/Aramaic component ( $10 \%$ to $25 \%$ of its vocabulary, according to various estimates), in a certain context almost every Hebrew word or expression can be a part of Yiddish. Therefore, while a sophisticated linguistic conceptual apparatus has been developed (including such concepts as 'Whole Hebrew vs. Merged Hebrew'), it is sometimes impossible to distinguish between a 'foreign' Hebrew word borrowed in a Yiddish text from a 'native' Yiddish word of Hebrew origin [17].

Although Hebrew and Yiddish both use Hebrew letters, they use radically different orthography. Hebrew orthography is a consonant one with letters representing only consonant phonemes (with some exceptions). Yiddish developed a phonemic orthography with letters representing both consonant and vowel phonemes and/or sounds. Thus, Hebrew letter 'ayin in Yiddish designates [e], letter komez-'alef designates [o], pasah-zvey-yuden is [ay], and so on. Despite that, orthography can hardly be an indicator of whether the word is in Hebrew or in Yiddish. This is in part because Yiddish lexica of the Hebrew component is written in Hebrew orthography (despite being a part of Yiddish). Furthermore, Yiddish orthography is used in Ashkenazi Hebrew texts when foreign words of non-Yiddish origin are used [14].

Epitaphs are written almost exclusively in Hebrew. Yiddish epitaphs are rare. However, the use of orthography code-switching represents the same trend: the traditional Hebrew (consonant) orthography is used for words and concepts of Biblical origin, while the phonetic or phonemic (Yiddish) orthography is used for profane or non-biblical realities. Example:

\section{שטערקבשרגר יעקב 'במ משה מהורר התורני}

A Torah man, R. Moses son of Jacob Šterkberger (1666 C.E., Trostyanec).

Note that in Germanic last name "Šterkberger" letter ע עayin is used for [e] (not שרקרגר as it would be spelled in accordance to the consonant Hebrew orthography).

An interesting example of how different orthographies relate to the sacred texts and to the everyday life is found in one of the oldest Ashkenazi inscriptions from Eastern Europe, the 1520 C.E. epitaph from Busk [7].

נתן פּאר תחת אפָר כי פּה נטמן איש נאמן ר' יהודא בן ר' יעקב דמתקרי ליודא

Gave jewelry instead of the ash (cf. Is 61:3), because here lies a reliable man, R. Yehuda, son of R. Jacob, who was nicknamed Ide (Busk 1520).

Ide and Yehuda (often spelled יהודא with 'alef to avoid a combination of letters constituting the God's name) are essentially the same name. Although in accordance to the modern Hebrew pronunciation they would be pronounced differently, the Ashkenazi Hebrew dialect reading would be 
the same. The juxtaposition of these two names makes sense only as a written (not oral) comparison between (Biblical) יודא from Busk.

We can make an important conclusion that the use of Hebrew or Yiddish orthography marks whether a particular word (and realities designated by the word) are found in the Hebrew sacred text or if the word is only related to everyday mundane reality.

Thus we observe the same pattern of the actualization of a sacred text, or the bridging between the realm of the sacred texts and the realm of the everyday life, whereas the epitaph constitutes a tool to construct such a bridge.

\subsection{Between the Canonical and Popular Religion}

The Hebrew religious law (halakah) does not stipulate what should be written in an epitaph [5], [8]. Furthermore, the very custom of writing and reading epitaphs is considered by Talmudic sages somewhat undesirable and, perhaps, it is associated with Hellenism or other pagan beliefs. The sages said:

אין עושין נפשות לצדיקים דבריהם הם זכרם

Do not build a monument for the righteous, their words are their monument (Babylonian Talmud, Mekilt'a 11:7).

Reading epitaphs is mentioned among ten activities which distract a learner or even weaken his memory:

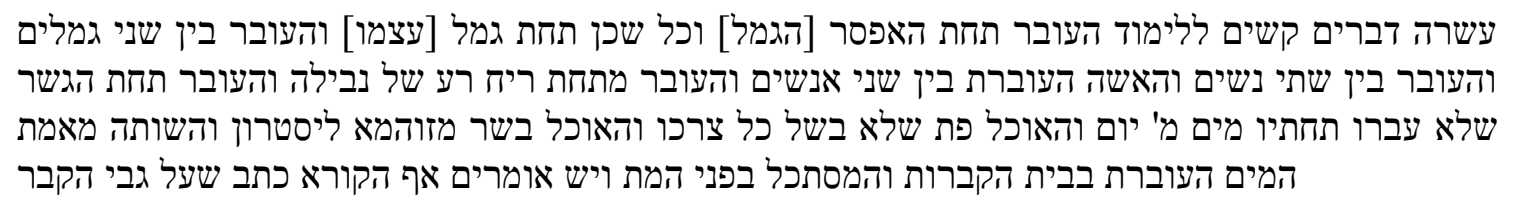

Ten things adversely affect one's study: Passing under the bit of a camel and much more so under the camel itself, passing between two camels, passing between two women, the passing of a woman between two men, passing under the offensive odor of a carcass, passing under a bridge under which water has not flowed for forty days, eating bread that was insufficiently baked, eating meat out of a soup-ladle, drinking from a streamlet that runs through a graveyard, and looking into the face of a dead body. Others say: $\mathrm{He}$ who reads an inscription upon a grave (Babylonian Talmud, Horayot 13b).

One can conclude from this, that reading epitaphs was considered an idle and undesirable activity and perhaps even that the epitaphs were not intended to an occasional human reader, but rather for the eternity. The use of sophisticated chronograms to denote the year in some inscriptions, which significantly complicate deciphering and increase the possibility of a mistake, also suggests that providing information about the year to an occasional reader was not a priority of the composers of the inscriptions.

Although the Jewish religious law does not stipulate what should be included into an epitaph, the epitaphs are generally perceived as something belonging to the realm of sacred or religious, as most activities related to death and its rituals. Thus the epitaphs fill a niche between the official religion and folk religious practice, bridging the gap between these two existential areas [14].

There are several functions of an epitaph. First, the gravestone serves as a marker of a ritually unclean place so that the Kohanim (decedents of the biblical priests, who are prohibited from touching 
the dead body or entering a cemetery) avoid it. In addition, the gravestone marks the place where some contact with the soul of the dead is possible. Second, an epitaph is a prayer. By reading an inscription one also reads the prayer for the dead. Some epitaphs in some regions use entire commemorative prayer 'El male' rahamim ('God full of Mercy'). Third, an epitaph is evidence of the virtues of the dead and of the sorrow of the survivors, to help for a good decision of his/her fate in the heavenly court. A didactic function of reminding about the death to survivors, which is very common for Christian and Ancient (cf. Latin 'Sta, viator', 'Traveler, pause') epitaphs, is rare in Jewish epitaphs. Most epitaphs have no narrator and no intended reader. The figure of an intended reader is absent from the epitaphs as well. God is the intended reader.

\subsection{Between the Professional and Folk Literature}

Looking at the epitaphs as a literature phenomenon, one finds a situation very similar to that in the case of the epitaphs as a religious phenomenon. Gravestone inscriptions are obviously related to the big literature, of which the epitaph is a traditional genre. Furthermore, there are poetic epitaphs which are related to the traditional Hebrew genres of קינה qinah ('elegy') and הספד hesped ('lamentation'), which,

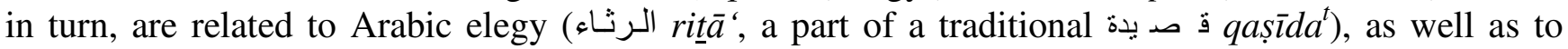
European poetry genres.

One of the main differences between the professional and folk literature is that a folk text has neither a single author nor a canonical version. There are many authors who contribute to the shaping of such a text which usually exists in many versions.

Some epitaphs have had known authors. However, the majority of these short texts are composed by anonymous authors using the formulas of previous epitaphs. There is evidence that in some places collections of standard parts and formulas of epitaphs existed, which were based on earlier inscriptions. Relatives of the deceased could select parts of these previous epitaphs to carve on the gravestone to commemorate the person. This is a mechanism very similar to how a folk text exists by combining a new version of the text from the parts of earlier versions.

It is well established by the structural anthropology, that there is a limited number of plots in a folk fairy tale. In an epitaph, there is in essence only one single plot: a person of good virtues has died on a particular day and has been buried at a particular place, with the hope that his soul will be bound in the 'bundle of life.'

\section{Hermeneutics of the Epitaphs}

The way of how an epitaph handles biblical quotations is quite sophisticated. Although at the surface level the Bible is being cited, a more scrutinized analysis shows that rabbinical or liturgical text, which cite the Bible, are indeed cited in many cases.

For example, the common final blessing (תהי נפשו צרורה בצרור החיים) תנצבה (May his/her soul be bound in the Bundle of Life' is technically a reminiscence to 1 Samuel 25:29. However, the blessing has a radically different meaning from the original verse in the Book of Samuel:

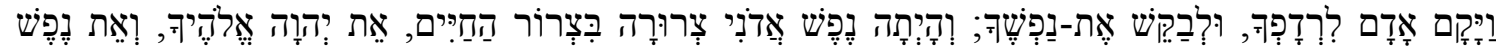

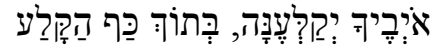

And though man be risen up to pursue thee, and to seek thy soul, yet the soul of my lord shall be bound in the bundle of life with the Lord thy God; and the souls of thine enemies, them shall he sling out, as from the hollow of a sling. 
The verse in the Book of Samuel does not imply the afterlife, while 'a soul bound in the bundle of life' means staying safe and alive. The Talmudic interpretation of this verse is different. It is concerned about the fate of the body and of the soul after death and it starts with the discussion of a different verse, Ecclesiastes 12:7:

Our Rabbis taught: 'And the dust return to the earth as it was, and the spirit return unto God who gave it' (Ecclesiastes 12:17): Render it back to him as He gave it to thee, [viz.,] in purity, so do thou [return it] in purity... The Holy One, blessed be He: concerning the bodies of the righteous He says, 'He entereth into peace, they rest in their beds' (Isaiah 57:2); while concerning their souls He says, 'yet the soul of my Lord shall be bound up in the bundle of life with the Lord thy God' (1 Samuel 25:29). But concerning the bodies of the wicked He says, 'There is no peace saith the Lord, unto the wicked" (Isaiah 48:22); while concerning their souls He says, and 'the souls of thine enemies, them shall he sling out, as from the hollow of a sling' (1 Samuel 25:29).

It was taught, R. Eliezer said: The souls of the righteous are hidden under the Throne of Glory, as it is said, 'yet the soul of thine Lord shall be bound up in the bundle of life' (1 Samuel 25:29). But those of the wicked continue to be imprisoned, while one angel stands at one end of the world and a second stands at the other end, and they sling their souls to each other, for it is said, 'and the souls of thine enemies, them shall he sling out, as from the hollow of a sling' (1 Samuel 25:29) (Babylonian Talmud, Šabbat 152b).

According to this interpretation, the Bundle of Life is a certain place under the Throne of Glory, from which the souls are taken when placed into the bodies and to which the souls of righteous people return after their death [1]. The Talmud also says that angels greet the souls of righteous people by these words, 'May his/her soul be bound in the Bundle of Life.'

Due to this interpretation, the verse is cited in rabbinical and liturgical literature. The Yizkor commemoration prayer says: 'May his soul be bound in the bundle of life together with the souls of Abraham, Isaac, Jacob, Sarah, Rebecca, Rachel, and Lea, and with the rest of righteous men and women, who are in the Garden of Eden.'

An epitaph with the formula תנצבה essentially cites the commemorative prayer, which, in term, cites the Talmudic interpretation of the Biblical verse, rather than the verse itself. Thus the citation is indirect and it employs the scheme:

The Bible $\rightarrow$ Talmudic interpretations $\rightarrow$ Liturgical texts $\rightarrow$ Epitaphs.

Another example is the above-mentioned epitaph of Miriam from Buczacz. The phrase ותקח

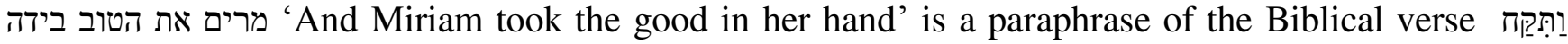

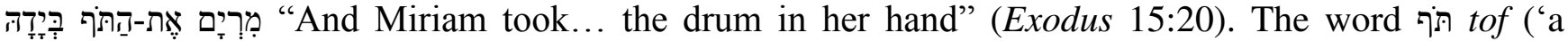
drum') is substituted by a similarly sounding word טוב tov (pronounced tof in a Yiddish dialect, 'the Good').

One could assume that the pun was invented by the author of the epitaph. However, the case can be more complicated, since a similar formula with the same pun (tov instead of tof) was found in another epitaph from Warsaw (geographically quite far away) [5]. An independent invention of the same pun is unlikely. It is much more probable that in both cases the phrase was borrowed from a certain written source:

The Bible $\rightarrow$ a rabbinical source $\rightarrow$ Epitaphs. 
These two examples illustrate a general principle: Biblical verses are usually quoted in the traditional texts through the lenses of Rabbinical texts and commentaries.

Another important hermeneutic feature of the epitaphs is their above mentioned relation to the internal Jewish bilingualism. While the 'Internal Jewish Bilingualism' is a scholastic concept developed by academic scholars, particularly, Yiddish linguists such as Max Weinreich, Uriel Weinreich, and Joshua Fishman, the theory of the Hebrew-Aramaic bilingualism (and, to a lesser extent, of the Hebrew-Yiddish bilingualism) was also elaborated by Rabbinical authors.

It is not just that Hebrew is a male and Yiddish is a female language in a symbolic sense or that Hebrew is the language of the Written Torah, while Aramaic is the language of the Oral Torah. Hebrew is called לשון קודש lašon-qodeš ('the sacred language') while Aramaic is called תשון lešon targum ('the language of the Translation'). Torah verses are supposed to be studied three times פעמיים מקרא פעם 'Twice the Scripture, once the [Aramaic] Translation.' This is not a random requirement. The ability to translate a text from the Sacred Language into a spoken language constitutes an important level of understanding the text.

Furthermore, the Aramaic language was viewed as an intermediate layer between the Hebrew language and the seventy languages of the peoples of the world (according to a traditional view, there are seventy nations in the world). Thus according to the Lurianic Qabbalah and, in particular, Rabbi Isaiah Horowitz (Šela ha-Qadoš, 1565 - 1630), the Aramaic language corresponds to the intermediate layer קליפת נגה (qelippat nogah) between the holy and the profane. The Talmud states that the 'Ministering Angels' (מלאכי השרת) do not understand Aramaic. This is because otherwise there would be a temptation to equate it in status with Hebrew:

A King talks about his needs to his servants, but he rarely talks to his ministers and only in a regal manner, so that nobody would think that they are equal to him. And about the servants nobody would assume that they are equal to the King, so there is no concern. Therefore, the ministering angels need every language and there is no concern, but with Aramaic there is a concern [2].

Judah Loew ben Bezalel (Maharal of Prague, d. 1609) has developed an elaborated theory, according to which the Aramaic language is a universal language of mankind but it does not belong to any particular nation (among the 'seventy nations of the world'), whereas Hebrew is a particular language of the Jewish people. Maharal writes:

May the Prayer be recited in any language? Behold Rab Judah has said: A man should never pray for his needs in Aramaic. For R. Johanan declared: If anyone prays for his needs in Aramaic, the Ministering Angels do not pay attention to him, because they do not understand that language! (Babilonian Talmud, Soțah 33a)

The principal meaning is that the Ministering Angels do not understand the Aramaic language at all, as it is not even called 'a language'. As I explained on Megillah 10b on 'And I took a name from Babylonia...,' they do not have writing and language. The Aramaic language is not a part of the seventy languages, although it is a language, it is not among the seventy created by the Holy One, blessed be he. Why Aramaic is not among the seventy languages? Because it is said in Sukkah 52a about the Chaldeans that 'they will not be a people'... The Torah paid respect to the Aramaic language; however, it does not belong to the seventy languages of the peoples of the world. This is because among the angels there are seventy appointed as ministers over the peoples of the world, however, the angels have no connection to the Aramaic language [3]. 
Maharal further claims that Aramaic was the language of Adam, the first human (and thus this language is universal), and that Aramaic is the language of the messianic future world, explaining the rule 'the Scripture twice, the [Aramaic] Translation (Targum) once':

The Translation is the degree of the World to Come because it is not considered a language at all, as it is said 'And I took a name from Babylonia...' (Megillah 10b) is about the Chaldeans who have no writing and language of their own. As we explained in a different place, the Aramaic language or the language of Babylonia is not considered a language. Its essence is thought, and thought corresponds to the highest degree of the World to come, this is 'Translation once'. In addition, the Ministering Angels do not understand Aramaic, and 'Translation once' is because it corresponds to the World to Come, as it is known that it belongs to Israel and not to the angels [4].

'Rabbi Juda said on behalf of Rava: Adam, the first man, spoke Aramaic' (Babilonian Talmud, Sanhedrin 38b) The meaning is that neither the Holy Language nor the rest of the seventy languages were appropriate for him. Because the Holy Language is a particular language of one nation, and the seventy languages as well. For Adam to master every language that originated from him, a particular language was inappropriate. However, he had the Aramaic language [3].

Rabbi Nachman of Breslov (1772 - 1810) wrote that the world was left imperfect in order to leave for a man space to finish some work and to improve the world thus co-creating the world together with the Lord [10]. This is similar to how, when a baby boy is born uncircumcised and thus 'imperfect', the circumcision should be performed. Only with the Targum (Aramaic translation) the holy language would become perfect. Biblical Joseph had a perfect knowledge of Hebrew, which involved the ability to translate into other languages. This is indicated by Joseph's ability to interpret dreams, as the word ת תרדמה tardemah ('dream') has the same gematri'a as the word תרגום targumslation').

Other Chassidic Rabbis claimed that in the modern time, Yiddish played the same role as Aramaic in the time of Talmud. The Rebbe from Vilednik said that by filling the Germanic language with Hebrew words (which is the case in Yiddish) the Jews bring the holiness to a non-Jewish language and thus accelerate the coming of the Messiah [19]

We see how the idea of translation from the holy language is related to more general concepts of the actualization of a sacred text and its interpretation, which is one of the functions of an epitaph.

\section{Conclusion}

Hebrew epitaphs are rarely studied as Jewish religious texts. Despite that, epitaphs demonstrate various features similar to the rabbinical and other Jewish traditional texts and genres. The most prominent among these features is the actualization of the sacred text by relating it to the everyday realities. This is achieved by proper biblical quotations and by orthography code-switching. The techniques are somewhat similar to the rabbinical hermeneutic approaches. Biblical quotations are often indirect so that the epitaphs cite liturgical and rabbinical texts citing biblical verses, rather than directly citing the biblical verses.

One of the central themes of the Jewish culture is its relationship to texts and, in particular, to texts in different languages. An important feature of this relationship is its bilingualism, with Hebrew being the language of the sacred texts and Aramaic or Yiddish being the language of everyday life. The translation from the holy language into the language of the everyday use is considered an important tool of the actualization of the sacred texts. While epitaphs are written in Hebrew, the traces of 
Hebrew/Yiddish orthography switching can be found in them when they switch between the biblical and mundane realities.

To summarize in one sentence, Hebrew epitaphs are a bridge between the realms of the canonical texts and of the everyday life of the Jewish community, which employ traditional rabbinical hermeneutic tools for the actualization of the sacred texts.

\section{References}

1. Fogelman, M. Tehe nišmato zerura bi-zeror ha-ḥayim, Sinay, 49, 1961, pp. 176-180 (in Hebrew).

2. Isserles, Moses ben Israel 'Orah Hayim, 472.4 gloss 2 Lemberg: .S.L. Kugel, 1866

3. Judah Loew ben Bezalel (ha-Maharal from Prague), Hidduše 'Aggadot, Soțah 33a, Jerusalem: 1972 (in Hebrew).

4. Judah Loew ben Bezalel (ha-Maharal from Prague), Tiferet Yiśra'el, 13, Kiryat Yoel: 2007 (in Hebrew).

5. Heilman, S. When a Jew Dies, Berkley: University of California Press, 2001.

6. Horowitz, Isaiah (Šela), Šney luḥot habrit, Pesaḥim, Maẓa Šemura Jerusalem : E. Munk, 1992 (in Hebrew).

7. Horst, Van der, P. W. Ancient Jewish Epitaphs: an Introductory Survey of a Millennium of Jewish Funeral Epigraphy (300 BCE - 700 CE), Kok Pharos: Kampen, 1991.

8. Kraemer, D. The Meanings of Death in Rabbinical Judaism, London, New York: Routledge, 2000.

9. Krajewska, M. Cmentarze żydowskie w Polsce: nagrobki i epitafia, Polska sztuka ludowa, 1-2, 1989, pp. 27-44.

10. Nahman of Bratzlav, Liqute Moharan, New York, 1966, Liqute Moharan 1:19.

11. Nahon, G. Inscriptions hebraiques et juives de France medievale, Paris: Belle Lettres, 1986.

12. Nosonovsky, M. Hebrew epitaphs of the 16th century from Ukraine, Monuments of Culture: New Discoveries - 1998, Nauka, Moscow, 1999, pp. 16-27 (in Russian).

13. Nosonovsky, M. The scholastic lexicon in Ashkenazi Hebrew and orthography, Pinkas. Journal of the Culture and History of East European Jewry, 2, Zara, Vilnius, 2008, pp 53-76.

14. Nosonovsky, M. Folk beliefs, mystics and superstitions in Ashkenazi and Karaite tombstone inscriptions from Ukraine, Markers, 26, 2009, pp. 120-147.

15. Nosonovsky, M. Old Jewish Cemeteries in Ukraine: History, Monuments, Epitaphs, In. M. Chlenov (ed.), The Euro-Asian Jewish Yearbook - 5768 (2007/2008), Moscow: Pallada, pp. 237-261.

16. Weinreich M. History of the Yiddish Language, New Haven, CT: Yale University Press, 2008.

17. Shapira D. Yiddish-German, Slavic, or Oriental?, Karadeniz Araştırmalart, 6, 2010, pp. 127-140.

18. Wodziński, M. Groby cadyków w Polsce. O chasydzkiej literaturze nagrobnej i jej kontekstach, Wrocław: Towarzystwo Przyjaciół Polonistyki Wrocławskiej, 1998.

19. Yiśra'el Yosef Dov Ber of Vilednik, Še'arit Yiśra'el, Zemanim, Šavuot 6 (in Hebrew). 